\title{
Status of seroprevalence of Hepatitis B in pregnant females: a hospital- based study
}

\author{
Rojaleen Das, Shilpee Kumar*
}

Department of Microbiology, Vardhman Mahavir Medical College and Safdarjung Hospital, New Delhi, India

Received: 06 October 2019

Accepted: 31 October 2019

\section{*Correspondence:}

Dr. Shilpee Kumar,

E-mail: drshilpee17@yahoo.in

Copyright: (C) the author(s), publisher and licensee Medip Academy. This is an open-access article distributed under the terms of the Creative Commons Attribution Non-Commercial License, which permits unrestricted non-commercial use, distribution, and reproduction in any medium, provided the original work is properly cited.

\begin{abstract}
Background: India has more than 37 million of HBV carriers and contributes a large proportion of the global burden. The perinatal route is the major route of the transmission. This study was conducted to estimate the seroprevalence rate of Hepatits B infection in female of reproductive age group. Since sexual route and perinatal transmission of $\mathrm{HBV}$ are major targets to prevent the transmission of the infection, the study focused on pregnant females attending antenatal care (ANC) clinic of the hospital.

Methods: This was a retrospective observational study. The cohort enrolled for the study was pregnant females who attended the antenatal care clinic of a tertiary care hospital situated in Delhi. The blood sample was collected as a part of routine screening for $\mathrm{HBV}$ infection and the samples were tested for HBsAg by qualitative indirect ELISA. The study period was March to Sept 2019.

Results: 7163 pregnant females were enrolled in the study and 113 were sero-positive for HBsAg. The seroprevalence of HBsAg was 1.6\% (113/ 7163). The highest prevalence was found in the age group of 31-35 year $(2.7 \%)$.

Conclusions: As observed in the present study, the sero-prevalence rate of HBV infection in pregnant females is $1.6 \%$, this rate amounts to nearly 4 million HBV infected women in the reproductive age and yearly putting 4 lakhs babies at risk of acquiring HBV infections by vertical transmission. The successful implementation of the National Viral Hepatitis Control Program is the need of the hour to protect every child from acquiring HBV infection.
\end{abstract}

Keywords: HBsAg, Hepatitis B, Pregnant women, Seroprevalence

\section{INTRODUCTION}

Viral hepatitis caused 1.34 million deaths in 2015, a number comparable to deaths caused by tuberculosis and higher than those caused by Human Immunodeficiency Virus (HIV) did. Most viral hepatitis deaths in 2015 were due to chronic liver disease $(720,000$ deaths due to cirrhosis) and primary liver cancer (470,000 deaths due to hepatocellular carcinoma). Globally, in 2015, an estimated 257 million people were living with chronic Hepatitis B Virus (HBV) infection. ${ }^{1}$ India alone has more than 37 million of $\mathrm{HBV}$ carriers and contributes a large proportion of the global burden. ${ }^{2}$ The chronically HBV infected people becomes reservoir of the infection and spread it through various routes like sexual, vertical transmission, intravenous, infected blood transfusions etc. In India, perinatal route of transmission is the major route of transmission. ${ }^{3}$ The risk of developing chronic infection is $90 \%$ following infection within 6 months of age and decreases to $20-60 \%$ between the ages of 6 months and 5 years. The HBsAg seropositivity in children attending outpatient clinic without liver problem is 2.14 to $2.25 \%$ under 5 years of age and 4.3 to $7.2 \%$ under 12 years of age. ${ }^{4}$ 
The disease spectrum of HBV infections ranges from chronic hepatitis to hepatocellular carcinoma (HCC) and can be prevented by an efficient recombinant vaccine against HBsAg. Following the launch of the Global Alliance for Vaccines and Immunization (GAVI) to intensify National Immunization Programs (NIPs) in developing countries, World Health Organization (WHO) recommends that Hepatitis $\mathrm{B}$ vaccine should be given to all infants. ${ }^{5}$ In India, Introduction of $\mathrm{HBV}$ vaccine was pilot-tested in 14 cities and 33 Districts in 2002-03 and extended to 10 States in 2007-08. The immunization was expanded to the entire country in 2011-12 under Universal Immunization Program (UIP). ${ }^{6}$ The UIP schedule of India recommends Hepatitis B vaccine to all infants within 24 hours of birth, followed by three doses at 6,10 and 14 weeks to complete the schedule. In case of an un-immunized adult, the vaccine administered at 0,1 and 6 months. $^{7}$

This study was conducted to estimate the seroprevalance Hepatits B virus infection in female of reproductive age group. Since sexual route and perinatal transmission of HBV are major targets to prevent the transmission of the infection, the study focused on pregnant females attending antenatal care (ANC) clinic of the hospital.

\section{METHODS}

The study was a hospital based retrospective observational study.

The study was conducted at the hospital that is 2800 bedded, tertiary care, government hospital situated in Delhi, North India. Its catchment area includes Delhi and neighboring states with daily average out-patient department visits of 11141 per day and in Antenatal care clinic it is 333 pregnant women per day. The test to detect HBV infection was conducted at the Department of Microbiology.

\section{Inclusion criteria}

- The cohort enrolled for the study was pregnant female who attended antenatal clinic of the hospital between March to September 2019.

Sample collection and processing: The blood sample was collected as a part of first trimester routine screening for Hepatitis B, HIV and syphilis as per national guidelines. ${ }^{3}$ Approximately $5 \mathrm{ml}$ of blood sample was collected in plain sterile tube and transported to the microbiology laboratory on the same day. The blood was allowed to clot at room temperature. The serum was separated by centrifugation at $1,000-2,000 \mathrm{x} \mathrm{g}$ for 10 minutes and stored at $2-8^{\circ} \mathrm{C}$ until test performed.

Testing of HBsAg: The samples were tested for presence of HBsAg in sera by enzyme linked immunosorbent assay (ELISA) using MONOLISA HBsAg ultra \#72346 (BIORAD, India) kit. The assay was a qualitative one- step enzyme immunoassay. Based on the principle of "sandwich" ELISA, the assay used monoclonal and polyclonal antibodies that bind to the various subtypes of WHO recognized HBsAg. The steps followed as per manufacturer's instruction and the results interpreted. The results reported as reactive/ non- reactive for $\mathrm{HBsAg}$ and the reactive samples considered as positive for Hepatitis B surface antigen.

\section{Statistical analysis}

All data points were coded and entered into excel sheet for further analysis. Analysis was performed using SPSS version 16 (SPSS for Windows; SPSS Inc., Chicago, IL). Categorical variables were compared using $\mathrm{z}$ test. All $\mathrm{P}$ values $<0.05$ were considered statistically significant.

\section{RESULTS}

A total 7163 pregnant females were enrolled in the study and 113 were sero-positive for HBsAg. The seroprevalence of HBsAg was $1.6 \%$ (113/ 7163). Depending upon the age group of seropositive women, the whole cohort was divided into groups with 5 years age interval as shown in Table 1 . The highest prevalence found in the age group of $31-35$ year $(2.7 \%)$. There were only few women of more than 35 years of age that attended ANC clinic hence the data censored while analyzing seroprevalence in different age group.

Table 1: Age wise distribution of pregnant women screened for $\mathrm{HBV}$ infection.

\begin{tabular}{|llll|}
\hline $\begin{array}{l}\text { Age } \\
\text { interval } \\
\text { (years) }\end{array}$ & $\begin{array}{l}\text { No. of } \\
\text { women } \\
\text { screened } \\
\text { for HBV } \\
\text { infection }\end{array}$ & $\begin{array}{l}\text { No. of } \\
\text { women } \\
\text { seropositive } \\
\text { for HB V }\end{array}$ & $\begin{array}{l}\text { Seroprevalence } \\
\text { of HBV } \\
\text { infection }(\%)\end{array}$ \\
\hline $16-20$ & 940 & 15 & 1.6 \\
\hline $21-25$ & 3658 & 52 & 1.4 \\
\hline $26-30$ & 2082 & 34 & 1.6 \\
\hline $31-35$ & 443 & 12 & 2.7 \\
\hline
\end{tabular}

The group with the age 31-35 seems to have higher positive cases proportion $(2.7 \%)$ compared to rest of the groups $(1.5 \%)$. Conducting a z-test on two samples (one sample of age-group 31-35 years and second sample being other three groups) results in p-value of 0.025 , confirming the age-group 31-35 is significantly different from rest of the population.

\section{DISCUSSION}

Based on the prevalence of HBV infection different region of the world are classified as high $(\geq 8 \%)$, intermediate $(2-7 \%)$ or low HBV endemicity $(<2 \%)$. India falls under the category of intermediate endemicity zone (average of 4\%). ${ }^{8}$ In India, Hepatitis B surface antigen (HBsAg) positivity in the general population 
ranges from $1.1 \%$ to $12.2 \%$, with an average prevalence of $3-4 \% .^{8}$ Perinatal transmission is the major route of transmission of $\mathrm{HBV}$ infection. ${ }^{3}$ In the absence of immune prophylaxis, the risk of transmission of $\mathrm{HBV}$ from mother to the baby is 70 to $90 \%$ by 6 months of age in the cases where mothers are tested positive for both HBsAg and HBeAg. This risk reduces to $10 \%$ where mothers are tested positive only for HBsAg positive and negative for HBeAg. ${ }^{9}$ Mother to infant infection of HBV can result in chronic HBV persistence, chronic hepatitis, cirrhosis, and hepatocellular carcinoma. In addition, chronic HBV status in childhood facilitates intra-familial transmission, particularly to siblings, as well as, transmission in preschools and daycare centers. ${ }^{10}$ To prevent mother-to child transmission of Hepatitis B, WHO recommends screening of all pregnant women for HBV and administration of Hepatitis B vaccine as birth dose to all infants and subsequently the three doses at 6 , 10 and 14 weeks. The situations where risk of transmission is high, like babies born to mothers who have detectable $\mathrm{HBeAg}$ and/or high viral load, Hepatitis B immunoglobulin (HBIG) should also be administered immediately after birth. ${ }^{3}$

Table 2: Different studies of HBV seroprevalence among pregnant women across north India.

\begin{tabular}{|c|c|c|c|c|}
\hline Study & Region & Year of study & Sample size & Seroprevalence of HBV \\
\hline Nayak et al ${ }^{11}$ & North India & 1987 & 8575 & $3.7 \%$ \\
\hline Mittal et al ${ }^{12}$ & Delhi (N. India) & 1996 & 850 & $6.3 \%$ \\
\hline Prakash et al ${ }^{13}$ & North India & $1992-97$ & 1112 & $9.5 \%$ \\
\hline Abass et al ${ }^{14}$ & Delhi (N. India) & 2001 & 6910 & $1 \%$ \\
\hline Pande et al $^{10}$ & Delhi (N. India) & 2004-08 & 20104 & $1.1 \%$ \\
\hline Sibia $\mathrm{P}$ et $\mathrm{al}^{15}$ & North India & 2013-14 & 3686 & $1.11 \%$ \\
\hline Garg $R$ et al ${ }^{16}$ & Agra (N. India) & $2015-16$ & 2058 & $2.04 \%$ \\
\hline Present study & Delhi (N. India) & 2019 & 7163 & $1.6 \%$ \\
\hline
\end{tabular}

In the present study, pregnant women attending ANC clinic of the hospital were screened for HBV infection. In total, 7163 were screened and HBsAg was positive in 113 women. The sero-prevalence of HbsAg was $1.6 \%$. Table 2 summarizes different sero-prevalence of $\mathrm{HBsAg}$ in pregnant females in North India in different years.

As observed in Table 2 there is reduction in seroprevalence of HBV infection in pregnant women in 2000s when compared to 1990s. However, there is marked variation in the seroprevalence rate in these studies even within same geographical area and timeframe. Such variation may occur due to different study model and sampling bias. When the study is community based the selected population may not be the true representative of the community. For example, it has been observed that certain pockets of community and tribal population have higher seroprevalence rate. ${ }^{4}$ When the study is hospital based, there may be patients who are showing symptoms of viral illness and referred to the hospital. This may again lead to overestimation of the seroprevalence rate. The test method to detect $\mathrm{HBsAg}$ may also affect the result of the study. The ELISA based tests are considered more sensitive than immunochromatographic based test but need skilled technician and expensive equipment to run the tests. The performance specification of the kits to detect $\mathrm{HBsAg}$ may also influence the result of the study.

As mentioned in Table 1, although highest number of HBsAg positive patients belongs to the age group of 21 to
25 years, the highest seropositivity rate observed in the age group of 31 to 35 years. Similar results observed by Sibia et al, however Rajendiran S et al, observed highest positivity rate in 25 to 30 years age group. ${ }^{15,17}$

The total population of India is 1.3 billion, amongst which 239 million women are in their reproductive age group and the birth rate is 20 births/ 1000 population per year. ${ }^{18}$ As observed in the present study, the seroprevalence rate of $\mathrm{HBV}$ infection in pregnant females is $1.6 \%$, this rate amounts to nearly 4 million HBV infected women in the reproductive age and yearly putting 4 lakhs babies at risk of acquiring $\mathrm{HBV}$ infections by vertical transmission.

The Government of India (GoI) is committed to achieve significant reduction in the infected population, morbidity and mortality associated with Hepatitis B. ${ }^{7,8}$ To achieve this goal the government has launched National Viral Hepatitis Control Program (NVHCP) for prevention and control of viral hepatitis in 2018 , with a view to provide free of charge screening, diagnosis, treatment and counselling services to all, and specially to people belonging to high-risk groups. The successful implementation of the program is the need of the hour to protect every child from acquiring HBV infection.

\section{CONCLUSION}

As observed in the present study, the sero-prevalence rate of $\mathrm{HBV}$ infection in pregnant females is $1.6 \%$, this rate 
amounts to nearly 4 million HBV infected women in the reproductive age and yearly putting 4 lakhs babies at risk of acquiring HBV infections by vertical transmission. The successful implementation of the National Viral Hepatitis Control Program is the need of the hour to protect every child from acquiring $\mathrm{HBV}$ infection.

Funding: No funding sources

Conflict of interest: None declared

Ethical approval: Not required

\section{REFERENCES}

1. World Health Organization. Global Hepatitis Report 2017. Available at: https://www.who.int/hepatitis/ publications/global-hepatitis-report2017/en/.

2. Puri P. Tackling the Hepatitis B disease burden in India. J Clin Exp Hepatol. 2014;4(4):312-9.

3. Ministry of Health and Family Welfare, Government of India. Technical guidelines for diagnosis and management of Hepatitis B, 2019. Available at: https://mohfw.gov.in/sites/default/files/Technical\%2 0and\%20Operational\%20_LOW\%20RISE.pdf.

4. Ray G. Current scenario of hepatitis B and its treatment in India. J Clin Transl Hepatol. 2017;5(3):277-96.

5. Verma R, Khanna P, Prinja S, Rajput M, Chawla S, Bairwa M. Hepatitis B vaccine in national immunization schedule: a preventive step in India. Hum Vaccin. 2011;7(12):1387-8.

6. John TJ. Hepatitis B Immunization in Public Health Mode in India. Indian Pediatr. 2014;51(11):869-70.

7. Ministry of Health and Family Welfare, Government of India. National viral hepatitis control program, Operational guidelines 2018. Available at: https://www.nhp.gov.in/national-viral-hepatitiscontrol-program-(nvhcp)_pg.

8. Ministry of Health and Family Welfare, Government of India. National Action Plan Combating Viral Hepatitis in India, 2019. Available at: https://mohfw.gov.in/sites/default/files/National\%20 Action\%20Plan_Lowress_Reference\%20file.pdf.

9. Geeta MG, Riyaz A. Prevention of Mother to Child Transmission of Hepatitis B Infection. Indian Pediatr. 2013;50:189-92.
10. Pande C, Sarin SK, Patra S, Bhutia K, Mishra SK, Pahuja S, et al. Prevalence, risk factors and virological profile of chronic hepatitis $B$ virus infection in pregnant women in India. J Med Virol. 2011;83(6):962-7.

11. Nayak NC, Panda SK, Zuckerman AJ, Bhan MK, Guha DK. Dynamics and impact of perinatal transmission of hepatitis B virus in North India. J Med Virol. 1987;21:137-45.

12. Mittal SK, Rao S, Rastogi A, Aggarwal V, Kumari S. Hepatitis B: potential of perinatal transmission in India. Trop Gastroenterol. 1996;17:190-2.

13. Prakash C, Sharma RS, Bhatia R, Verghese T, Datta K. Prevalence of North India of hepatitis B carrier state amongst pregnant women. Southeast Asian J Trop Med Public Health. 1998;29:80-4.

14. Abass F, Thomas RD, Rajkumar A, Gupta N, Puliyel JM. Controlling perinatally acquired hepatitis B. Indian J Pediatr. 2001;68:365.

15. Sibia P, Mohi MK, Kumar A. Seroprevalence of Hepatitis B infection among pregnant women in one of the institutes of Northern India. J Clin Diagn Res. 2016;10(8):8-9.

16. Garg R, Nigam AK, Singh S, Singh R, Singh S, Rani R, Malhotra J. Seroprevalence of Hepatitis B surface antigen among pregnant women in a tertiary care health center of North India. J South Asian Feder Obst Gynae. 2017;9(2):164-8.

17. Rajendiran S, Gopalan U, Jayakumar K. Seroprevalence of Hepatitis B infection among pregnant women in South India. Int $\mathbf{J}$ Reprod Contracept Obstet Gynecol. 2017;6(1):249-51.

18. Directorate General of Health Services. National Health Profile 2018. Central Bureau of Health Intelligence; Ministry of Health and Family Welfare. Available at: http://www.cbhidghs.nic.in/ WriteReadData/1892s/Before\%20Chapter1.pdf.

Cite this article as: Das R, Kumar S. Status of seroprevalence of Hepatitis B in pregnant females: a hospital-based study. Int J Reprod Contracept Obstet Gynecol 2019;8:4858-61. 